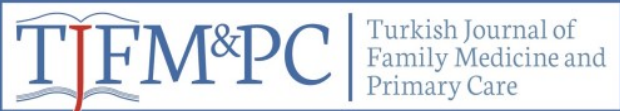

Original Research / Özgün Araştırma

\title{
Can Physical Complaints in High School Students be Symptoms of Internet Addiction?
}

\author{
Lise Öğrencilerinde Fiziksel Şikâyetler İnternet Bağımlılı̆̆ı Belirtisi Olabilir mi?
}

Gökmen Özceylan ${ }^{*}$, Dilek Toprak², Nurhan Doğan ${ }^{3}$

\begin{abstract}
Background: The aim of this study is to measure the level of internet addiction among high school adolescents and to determine the relationship between their time spent on the internet and the back and neck pain and eye health problems they experience.Methods: The study is a simple cross-sectional descriptive study. 8926 high school students participated in the study. Students were selected by cluster sampling method pursuant to their gender, school type, and grade distributions. Young's short internet addiction test (IAT) that was adapted to Turkish was utilized. Results: The average internet addiction score of the students was $26.88 \pm 8.80$. While the ratio of students with a high risk of addiction was $44.3 \%$ $(n=3950)$, the ratio of those, who were addicted, was $15.7 \%(n=1400)$. A significant positive correlation was found between the addiction level and the lower back, neck pain and eye disorders. $(\mathrm{p}<0.001 ; \mathrm{p}<0.001 ; \mathrm{p}<0.001)$ The smartphone possession rate of students was $96.4 \%$ ( $\mathrm{n}=8606)$. There was a significant positive correlation between having a smartphone and the level of addiction, neck pain, and eye complaints. $(\mathrm{p}=0.005$; $\mathrm{p}=0.002 ; \mathrm{p}=0.003$, respectively)The ratio of students, who have a computer at home, was $79.8 \%(\mathrm{n}=7122)$. Eye complaints were found to be significantly higher in those, who had a computer at home $(\mathrm{p}<0.001)$.Conclusion: Internet addiction is an important and common problem among adolescents. Internet addiction increases, as the age of adolescents increases. Smartphones are the most important risk factor for the spread of internet addiction. Internet addiction leads to muscle-joint pain, and eye-related symptoms.
\end{abstract}

Key words: Internet addiction, smartphone, eye disorders, musculoskelatal pain.

ÖZET

Giriş: Bu çalışmanın amacı lise çağındaki adelosanlarda internet bağımlılık düzeyini ölçmek, internette bulunma süresi ile bel, boyun ağrıları ve göz sağlı̆̆ı problemleri arasındaki ilişkiyi belirlemektir. Yöntem: Çalışma basit kesitsel tanımlayıcı bir çalışmadır. Çalışmaya 8926 lise öğrencisi katıldı. Öğrenciler cinsiyetlerine, okudukları okul tipi ve sınıf dağılımlarına göre küme örnekleme yöntemiyle seçildi. Türkçeye uyarlanmış Young'un kısa internet bağımlılık ölçeği (IAT) kullanıldı. Bulgular: Çalışmaya katılan öğrencilerin yaş ortalaması 15,71 $\pm 1,14$ idi (min=14, maks=18). Öğrencilerin ortalama internet bağımlılık puanı $26,88 \pm 8,80$ 'di (min=12, maks=60). Bağımlılık riski yüksek olan öğrencilerin oranı $\% 44,3(\mathrm{n}=3950)$ iken bağımlı olanların oranı \%15,7’di ( $\mathrm{n}=1400)$. Bağımlılık düzeyi ile bel, boyun ağrısı ve göz rahatsızlıkları arasında anlamlı pozitif ilişki tespit edildi $(\mathrm{p}<0,001 ; \mathrm{p}<0,001 ; \mathrm{p}<0,001)$. Öğrencilerin akıllı telefon sahibi olma oranı ise $\% 96,4^{\prime} t u ̈ ~(n=8606)$. Akı1lı telefon sahibi olmakla bağımlılık düzeyi, boyun ağrısı ve gözlerdeki şikâyetler arasında anlamlı bir pozitif ilişki saptandı (sırasıyla $p=0,005 ; p=0,002 ; p=0,003$ ). Çalışmada evinde bilgisayar bulunan öğrencilerin oranı \%79,8'di $(\mathrm{n}=7122)$. Evinde bilgisayar olanlarda gözlerdeki şikâyetlerin anlamlı olarak daha yüksek olduğu tespit edildi $(\mathrm{p}<0,001)$. Sonuç: Adelosanlarda internet bağımlılığı önemli ve yaygın bir sorundur. Adelosan yaşı arttıkça internet bağımlılı̆̆ da artmaktadır. Adolesanlar arasında çok yaygın kullanım oranı olan akıllı telefonlar internet bağımlılığının yaygınlaşması için en önemli risk faktörüdür. İnternet bağımlılığı kas-eklem ağrıları ve göz ile ilgili semptomlara sebep olmaktadır. Muayene sırasında bu ilişki de dikkate alınmalıdır.

Anahtar kelimeler: İnternet bağımlılığı, akıllı telefon, göz rahatsızlıkları, kas iskelet sistemi ağrıları

Received / Geliș tarihi: 11.10. 2020, Accepted / Kabul tarihi: 18. 12. 2020

${ }^{1}$ Ministry of Health, Family Medicine Center Reşadiye, Çorlu, Tekirdağ, TURKEY.

${ }^{2}$ Namık Kemal University, Department of Family Medicine,Tekirdağ, TURKEY.

${ }^{3}$ Afyonkarahisar Health Sciences University, Biostatistics and Medical Informatics, Afyonkarahisar,TURKEY.

*Address for Correspondence / Yazışma Adresi: Gökmen Özceylan, Ministry of Health, Family Medicine Center Reşadiye, Çorlu, Tekirdağ, TURKEY.

E-mail: gokmenozceylan01@hotmail.com

Ozceylan G, Toprak D, Dogan N. Can Physical Complaints in High School Students be Symptoms of Internet Addiction? TJFMPC, 2021;15(1): 154-163.

DOI: $10.21763 / \mathrm{tjfmpc} .808995$ 


\section{INTRODUCTION}

In recent years, it has been demonstrated by studies that 46-50 million people use internet in Turkey. The age group, in which internet use is the most common, is adolescents. Widespread use in this age group makes it imperative to examine the effects of internet addiction and its health implications. ${ }^{1,2}$

Health problems seen in adolescents vary due to age-related features. Recently, the effects of internet use, which is the new habit of this special age group, on health have been revealed by researchers in many studies. Internet use becoming an addiction, especially in adolescents, increases related health problems. ${ }^{3,4}$

Addiction is defined as the inability of a person to leave a substance or the emergence of certain symptoms when that person attempts to kick the said habit. $^{5}$ The definition of internet addiction was made for the first time in 1996 . $^{6}$ Internet addiction is the condition of not being able to control the use of the internet, which leads to disorders in mental, social, and behavioural functionality. ${ }^{7}$ Scientists are still trying to determine how long should be spent on the internet, after how long a user becomes addicted, and what type of health problems the addiction leads to. The final diagnostic criteria and treatment modalities for Internet addiction are still unclear. In the literature, anxiety, depressive behavior disorder, sleep disorders, headache, visual disturbances, and postural complaints (such as lower back and neck pains) come to the fore as the most common symptoms of spending time on the internet and social media for an extended duration of time. .,9,3 $^{8,3}$

The aim of this study is to measure the level of internet addiction among high school-age adolescents, and to determine the relationship between their time spent on the internet, and the back and neck pain and eye health problems they experience. The secondary purpose of the study is to increase the awareness of the physicians when it comes to the complaints that may be related to the internet addiction in primary health care institutions with the data obtained because of the study and to contribute to taking measures to protect the health of young people.

\section{MATERIALS AND METHODS}

The target population of study included all high school students of Çorlu, which is the district of Tekirdağ province, during the 2019-2020 educational period. The study approval was obtained from the Ethics Committee of Namik Kemal University on 27.06.2019 with the protocol 2019.115.07.11. Necessary permissions were obtained from Tekirdağ Provincial Directorate of National Education at the date of 29.05.2019 and number 43996270-44. The target population ( $\mathrm{n}=$ 14042) included all the students, whose parents gave permission, who volunteered to participate in the study and did not have musculoskeletal system and eye disorders that prevented them from partaking (such as scoliosis, kyphosis, kyphoscoliosis, vision loss, severe refractive error, and glaucoma). Participation rate was $63.56 \%(\mathrm{n}=$ 8926).

Random cluster sampling method was used while selecting participants in the study. School type and grade distribution of students in schools were clustered by gender. Those, who volunteered to participate in the study and did not have an obstacle for study participation, were listed in the cluster. These lists were selected as groups of 10 people, and the first seven people in each list were selected considering their gender distribution. The distribution of the number of students in high schools in Çorlu to the school type and gender is given in Table 1. The number of students was the official number of Çorlu District National Education Directorate in 2019.

\begin{tabular}{|c|c|c|c|c|c|c|}
\hline \multirow[b]{2}{*}{ Grade } & \multicolumn{2}{|c|}{ Public } & \multicolumn{2}{|c|}{ Private } & \multicolumn{2}{|c|}{ Total } \\
\hline & $\begin{array}{c}\text { Boy } \\
\text { n (\%) }\end{array}$ & $\begin{array}{c}\text { Girl } \\
\mathrm{n}(\%)\end{array}$ & $\begin{array}{c}\text { Boy } \\
\text { n (\%) }\end{array}$ & $\begin{array}{c}\text { Girl } \\
\mathrm{n}(\%)\end{array}$ & $\begin{array}{c}\text { Boy } \\
\text { n (\%) }\end{array}$ & $\begin{array}{c}\text { Girl } \\
\mathrm{n}(\%)\end{array}$ \\
\hline 9th Grade & $1687(12.0)$ & $1616(11.5)$ & $595(4.2)$ & $213(1.5)$ & $2282(16.3)$ & $1829(13.0)$ \\
\hline 10th Grade & $1251(8.9)$ & $1435(10.2)$ & $504(3.6)$ & $230(1.6)$ & $1755(12.5)$ & $373(11.9)$ \\
\hline 11th Grade & $1297(9.2)$ & $1309(9.3)$ & $418(3.0)$ & $293(2.1)$ & $1715(12.2)$ & $1602(11.4)$ \\
\hline 12th Grade & $1194(8.5)$ & $1309(9.3)$ & $385(2.7)$ & $306(2.2)$ & $1579(11.3)$ & $1615(11.5)$ \\
\hline Total & $5429(38.7)$ & $5669(40.4)$ & $1902(13.6)$ & $1042(7.4)$ & $7331(52.2)$ & $6711(47.8)$ \\
\hline
\end{tabular}

In this study, a 12-question IAT (Young's internet addiction test) adapted to Turkish as the questionnaire was used to measure the level of internet addiction. Reliability and validity study of the Turkish version of IAT, the internet addiction scale developed by Young was made by Mutlu et al. IAT Short Form Cronbach obtained in the reliability study alpha coefficient; 0.91 for 
university students, 0.86 in adolescents. ${ }^{10,11}$ In this questionnaire, the internet addiction scores were calculated by giving answers to 12 questions with a rating of 1 to 5 (never, rarely, sometimes, often, and always) according to Likert- type scale. The lowest value was 12, while the highest one was 60 . If the internet addiction score is between 12-23, the internet load is defined as normal, between 24-41 the risk of addiction was regarded as high, and between 42-60, the subjects were defined as addicted..$^{10}$ Both the questions asked about age, school, and grade information prepared by us, and the questions about back and neck pain, complaints of burning, stinging rashes in the eyes (these questions were arranged according to Likert- type scale) were added to the questionnaire. The questionnaire consisting of a total of 23 questions was uploaded to the google survey program and sent to the head principal of each school, so that students could fill it out.

In the study, the students were asked to fill out the questionnaire under the supervision of the teachers via smartphone or in classrooms via an interactive whiteboard. The data was analyzed in spss 16.0 statistics software. Internet addiction levels and complaints were scored, and each participant was analyzed according to their age, their gender, school types, school categories, and grade distributions. The schools that students attend were divided into two groups as public and private schools according to their paid status. Schools were grouped as Anatolian high schools, Vocational, and Technical high schools, and Science high schools according to their vocational education types. The descriptive statistics were given as follows; number and percentage for categorical variables; and mean, standard deviation, minimum, maximum, median for numerical variables. In comparison of independent groups, Chi-squared test was used for categorical data, and T-test was used for numerical data. The statistical significance level was accepted as $\mathrm{p}<0.05$.

\section{RESULTS}

In our study, in which a total of 8926 students participated, the average age of the whole group was $15.71 \pm 1.14(\min =14, \max =18)$. Distribution of the participants by age, gender, school type, school category, and grades are given in Table 2.

\begin{tabular}{|c|c|c|}
\hline & $\mathrm{n}$ & $\%$ \\
\hline $\begin{array}{l}14 \\
15 \\
16 \\
17 \\
18\end{array}$ & $\begin{array}{c}1560 \\
2418 \\
2378 \\
2169 \\
401\end{array}$ & $\begin{array}{c}17.5 \\
27.1 \\
26.6 \\
24.3 \\
4.5\end{array}$ \\
\hline $\begin{array}{r}\text { Male } \\
\text { Female }\end{array}$ & $\begin{array}{l}4659 \\
4267\end{array}$ & $\begin{array}{l}52.2 \\
47.8\end{array}$ \\
\hline $\begin{array}{r}\text { State school } \\
\text { Private School } \\
\end{array}$ & $\begin{array}{l}7060 \\
1866 \\
\end{array}$ & $\begin{array}{l}79.1 \\
20.9 \\
\end{array}$ \\
\hline $\begin{array}{r}\text { Anatolian High School } \\
\text { Vocational and Technical High School } \\
\text { Science High School }\end{array}$ & $\begin{array}{c}5101 \\
3168 \\
656\end{array}$ & $\begin{array}{c}57.2 \\
35.5 \\
7.4\end{array}$ \\
\hline $\begin{array}{l}\text { 9th Grade } \\
\text { 10th Grade } \\
11 \text { th Grade } \\
12 \text { th Grade }\end{array}$ & $\begin{array}{l}2609 \\
2192 \\
2109 \\
2016\end{array}$ & $\begin{array}{l}29.2 \\
24.6 \\
23.6 \\
22.6\end{array}$ \\
\hline
\end{tabular}

The average internet addiction score of all students participating in the study was $26.88 \pm 8.80$ according to IAT $(\min =12, \max =60)$. The proportion of students with normal addiction level calculated according to Internet addiction score was $40.1 \%(\mathrm{n}=3576)$. While the ratio of students with high risk of addiction was $44.3 \%(\mathrm{n}=3950)$, the ratio of those, who were addicted, was $15.7 \%$ ( $\mathrm{n}=$ 1400).
The meaningful relationship between the level of internet addiction of students participating in the study and low back pain, neck pain, itching, burning, and stinging in the eyes complaints is shown in Table 3. As the level of internet addiction among students increased, there was a significant increase in the incidence rate of all three groups of complaints $(\mathrm{p}<0.001)$. 


\begin{tabular}{|c|c|c|c|c|c|c|}
\hline Lower back pain & $\begin{array}{l}\text { Never } \\
\mathrm{n}(\%)\end{array}$ & $\begin{array}{c}\text { Rarely } \\
\mathrm{n}(\%)\end{array}$ & $\begin{array}{c}\text { Sometimes } \\
\mathrm{n}(\%)\end{array}$ & $\begin{array}{l}\text { Often } \\
\mathrm{n}(\%)\end{array}$ & $\begin{array}{c}\text { Always } \\
\mathrm{n}(\%)\end{array}$ & $P^{*}$ \\
\hline Normal & $1703(47.6)$ & $1106(30.9)$ & $514(14.4)$ & $163(4.6)$ & $90(2.5)$ & \multirow{3}{*}{$<0,001$} \\
\hline $\begin{array}{l}\text { High risk of } \\
\text { addiction }\end{array}$ & $1336(33.8)$ & $1214(30.7)$ & $914(23.1)$ & $328(8.3)$ & $158(4.0)$ & \\
\hline Addicted & $306(21.9)$ & $281(20.1)$ & $391(27.9)$ & $186(13.3)$ & $236(16.9)$ & \\
\hline \multicolumn{6}{|l|}{ Neck pain } & $P^{*}$ \\
\hline Normal & $1777(49.7)$ & $1107(31.0)$ & $469(13.1)$ & $147(4.1)$ & $76(2.1)$ & \multirow{3}{*}{$<0,001$} \\
\hline $\begin{array}{l}\text { High risk of } \\
\text { addiction }\end{array}$ & $1353(34.3)$ & $1275(32.3)$ & $862(21.8)$ & $316(8.0)$ & $144(3.6)$ & \\
\hline Addicted & $277(19.8)$ & $310(22.1)$ & $396(28.3)$ & $193(13.8)$ & $224(16.0)$ & \\
\hline \multicolumn{6}{|c|}{ Itching, burning, stinging, pain in the eyes } & $P^{*}$ \\
\hline Normal & $1831(51.2)$ & $1082(30.3)$ & $454(12.7)$ & $152(4.3)$ & $57(1.6)$ & \multirow{3}{*}{$<0,001$} \\
\hline $\begin{array}{l}\text { High risk of } \\
\text { addiction }\end{array}$ & $1295(32.8)$ & $1245(31.5)$ & 855 (21.6) & $381(9.6)$ & $174(4.4)$ & \\
\hline Addicted & 279 (19.9) & $286(20.4)$ & $331(23.6)$ & $238(17.0)$ & $266(19.0)$ & \\
\hline
\end{tabular}

*T Test in independent groups

Analysis of the level of addiction by age of students is presented in Table 4. Accordingly, the level of internet addiction was found to be significantly higher, especially in the 18 -year-old student group $(\mathrm{p}<0.001)$.

It was found that the level of addiction by gender was higher in girls than in boys, but this level was found to be significant only at the border $(\mathrm{p}=0.053)($ Table 4$)$.

While addiction rates were significantly high in students studying in private schools $(p<0.001)$, internet addiction rates were significantly higher in science high school and vocational high school students compared to Anatolian high school students $(\mathrm{p}<0.001)$ (Table 4).

Addiction ratios of 9 th and 10th grade students were found to be higher than 11th and 12 th grade students $(\mathrm{p}<0.001)$ (Table 4$)$.
Low back pain, neck pain, and complaints in the eyes were found to be significantly higher in the 18-year-old age group compared to other age groups ( $<<0.001 ; p=0.001 ; p=0.001$, respectively). Low back pain, neck pain, and complaints in the eyes were significantly higher in female students than in male students $(\mathrm{p}=0.002 ; \mathrm{p}<0.001$; $\mathrm{p}=0.001$, respectively).

While the rate of students who had a computer at home was $79.8 \%(n=7122)$, the rate of owning tablets was $26.4 \%(n=2359)$, and the rate of owning game consoles was $14.8 \%$ ( $\mathrm{n}=$ 1317). The smartphone possession rate of students was $96.4 \%(n=8606)$.

While there was a significant positive relationship between having a smartphone and addiction level and neck pain and complaints in the eyes $(p=0.005 ; p=0.002 ; p=0.003$, respectively), there was no significant relationship between having a smartphone and low back pain ( $\mathrm{p}>0.05)$. 
No significant relation was found between having a computer at home, addiction level, low back pain, neck pain ( $\mathrm{p}>0.05, \mathrm{p}>0.05, \mathrm{p}>0.05$, respectively).
There was a positive relationship between having a computer at home and eye-related complaints. Eye complaints were found to be significantly higher in those, who had a computer at home $(\mathrm{p}<0.001)$.

\begin{tabular}{|c|c|c|c|c|}
\hline & $\begin{array}{c}\text { Normal } \\
\mathrm{n}(\%)\end{array}$ & $\begin{array}{c}\text { High Addiction Potential } \\
\mathrm{n}(\%)\end{array}$ & $\begin{array}{l}\text { Addicted } \\
\mathrm{n}(\%)\end{array}$ & $\mathrm{P} * / * *$ \\
\hline $\begin{array}{c}\text { Age } \\
14 \\
15 \\
16 \\
17 \\
18\end{array}$ & $\begin{array}{l}650(41.7) \\
924(38.2) \\
913(38.4) \\
941(43.4) \\
148(36.9)\end{array}$ & $\begin{array}{c}688(44.1) \\
1099(45.5) \\
1079(45.4) \\
917(42.3) \\
167(41.6)\end{array}$ & $\begin{array}{c}222(14.2) \\
395(16.3) \\
386(16.2) \\
311(14.3) \\
86(21.4)\end{array}$ & $<0,001^{*}$ \\
\hline $\begin{array}{c}\text { Gender } \\
\text { Male } \\
\text { Female }\end{array}$ & $\begin{array}{l}1896(40.7) \\
1680(39.4)\end{array}$ & $\begin{array}{l}2074(44.5) \\
1876(44.0)\end{array}$ & $\begin{array}{l}690(14.8) \\
710(16.6)\end{array}$ & $0.053 * *$ \\
\hline $\begin{array}{c}\text { School type } \\
\text { Public } \\
\text { Private }\end{array}$ & $\begin{array}{l}925(41.4) \\
651(34.9)\end{array}$ & $\begin{array}{c}3084(43.7) \\
866(46.4)\end{array}$ & $\begin{array}{l}1051(14.9) \\
349(18.7)\end{array}$ & $<0,001 * *$ \\
\hline $\begin{array}{c}\text { School Category } \\
\text { Science High School } \\
\text { Vocational High } \\
\text { School } \\
\text { Anatolian High } \\
\text { School }\end{array}$ & $\begin{array}{c}218(33.2) \\
1224(38.6) \\
2134(41.8)\end{array}$ & $\begin{array}{c}320(48.8) \\
1394(44.0) \\
2236(43.8)\end{array}$ & $\begin{array}{l}118(18.0) \\
550(17.4) \\
732(14.3)\end{array}$ & $<0,001 * *$ \\
\hline $\begin{array}{l}\text { Grade } \\
\text { 9th Grade } \\
\text { 10th Grade } \\
\text { 11th Grade } \\
\text { 12th Grade }\end{array}$ & $\begin{array}{c}1030(39.5) \\
842(38.4) \\
819(38.8) \\
885(43.9)\end{array}$ & $\begin{array}{l}1148(44.0) \\
978(44.6) \\
997(47.3) \\
827(41.0)\end{array}$ & $\begin{array}{l}431(16.5) \\
372(17.0) \\
293(13.9) \\
304(15.1)\end{array}$ & $<0,001^{* *}$ \\
\hline
\end{tabular}

* Spearman correlation analysis

** T Test in independent groups

\section{DISCUSSION}

In our study, the relationship between high school students' addiction levels and three basic complaints (back pain, neck pain, and eye health problems) that were important for the adolescent period were evaluated, and it was found that these three complaints increased significantly as the level of internet addiction increased.

Adolescents and especially students are identified as high-risk group in internet addiction. In studies carried out until 2010, while adolescents were found to be approximately $2-8 \%$ internetaddicted, it was found that this rate jumped to $20 \%$ in recent years. Although it varies from country to country all over the world, internet addiction rate is stated to be between $0.3 \%$ and $38 \%$. ${ }^{12-16}$ In a metaanalysis study conducted in France, the prevalence of internet addiction in the USA and European countries was reported to vary between $1.5 \%$ and $18.5 \%$. ${ }^{17}$ In our study, the proportion of students who are similarly dependent is approximately $15 \%$, which indicates that this problem has become a global problem that concerns all countries. Necessary precautions should be taken in order not to increase this rate, which can be considered high even today.

In a meta-analysis study that included the studies conducted according to IAT scores, IAT of the students was determined to be $20.9 .{ }^{12}$ In a study including university students in Turkey, the score was found to be $26.85 .{ }^{13}$ In our study, the IAT score was found to be 26.88 , and approximately one in two students was found to have a high risk of addiction. This study is consistent with the literature in Turkey. This data shows that students in Turkey have higher IAT scores compared to other countries in the world. We believe that the most important reason for this is the lack of social activities of our youth in schools and outside school times. Sports, cultural and social activities for adolescents in Turkey should be increased and Turkish youth should be encouraged to partake in these events. In this way, we think that the time 
they spend on the internet can be reduced and the related health problems that may occur can be reduced.

The most important reason why some studies use test scores, and some use the notion of prevalence is due to the following; method differences in research, the fact that these methods are new among scientific cliques and the fact that the gathered data depends on cultural differences. Data from all studies conducted with prevalence or IAT scores also show that while dependency rates increase all over the world, the priority method to combat addiction should be the "fight against addiction" ${ }^{17}$ It is important to develop preventive, awareness-raising and educative projects for groups at risk before the internet addiction affects students' success and health.

There are studies showing that gender difference is important among the factors affecting internet addiction. ${ }^{18}$ There are studies indicating that internet addiction rates are higher in boys than girls. In two separate studies examining the internet addiction of university students in Iran, it has been shown that boys are approximately 5\% more internet addicted than girls. ${ }^{19}, 20$ In a study conducted in China, it was reported that internetaddiction in boys is approximately two times higher than in girls. ${ }^{21}$ In a study conducted for high school students in France, it has been shown that the internet usage time of boys is higher than girls, but the use of social media on the internet is higher in girls than boys. ${ }^{22}$ There are also studies in the literature showing that internet addiction does not change according to gender. ${ }^{23}$ In a meta-analysis that examined the studies which compared internet addiction by gender, it was reported that men have higher Internet usage time and higher IAT scores. In $89 \%$ of the literature studies examined in this meta-analysis study, it was found that men have higher IAT scores. ${ }^{24}$

In our study, unlike the literature, it was found that internet addiction among girls was moderately higher than boys but there was no significant difference between them. All the data and literature show that Internet addiction is an important health problem for both genders. In order to provide solutions to this problem of adolescents, preventive education projects are needed without separating both genders.

In a meta-analysis study involving the studies conducted according to IAT scores, especially in the adolescent age group, internet addiction was found to be approximately five times higher than other portions of society. ${ }^{12}$ In a comprehensive student study involving 8 regions in China, it was reported that as the age of adolescents increased, internet addiction also increased. In particular, while internet addiction is $8.3 \%$ at the secondary school level, this rate rises to $9 \%$ at high school age level. ${ }^{21}$ In a study conducted with high school students in Nigeria, it has been determined that the internet usage has increased with the increase in the age of adolescents, that the reasons for internet use changed, that the rate of internet use for sexual content has increased more with boys, while the use of internet for social media use has increased more with girls, as they became older. ${ }^{25}$ In another study, it was shown that as a student's grade increases and his/her age increases, the use of internet in students increases alongside it. In the study in Wuhan region in China, it has been shown that while internet addiction is around $8.9 \%$ at the ages of $13-14$, this rate reaches up to $20 \%$ at the ages of $19-20 .{ }^{26}$ In an internet addiction study conducted with 952 high school students in Turkey, it has been shown that the internet behavior types of students increased through interaction with their peers. It was determined that interaction with parents decreased in this period, and that peer interaction played an important role in this behaviour. ${ }^{27}$ In our study, a significant difference was found in accordance with the literature, especially in adolescents aged 18 years compared to other age groups. We think that the fact that university entrance exam in Turkey is carried out in the corresponding point of time and that the heaviest study load and stress is seen in high school students are in this period do play a role along with other reasons cited in the literature. Another important factor of high internet addiction in this age group is that we think that this addiction could decrease the success levels of high school students in an important test, in which they will determine their profession and lifestyles for the rest of their lives. High school student-oriented projects aimed at reducing the addiction of high school students must be initiated by giving priority to this age group. Especially when they apply to family health centers in this age group during the young and adolescent period follow-ups, family physicians should question the health problems that may be caused by exam stress, anxiety level and internet addiction in this approach.

There is not enough study in the literature to investigate the change of students' internet addiction according to the school they attend. However, students who live in families with high socioeconomic levels are reported to have higher internet addiction compared to other students. ${ }^{12,14,15}$ In our study, in accordance with the literature, the rate of IAT was found to be significantly high, especially among students studying in (paid) private schools. While the addiction rate is around $15 \%$ for students studying in public high schools, this rate reaches $20 \%$ in private schools. The data 
shows that children from families with high socioeconomic levels run a higher risk of internet addiction due to the easy economic cost of accessing the internet. There are literature studies showing that school types have an indirect effect on internet addiction according to their education styles. Accordingly, in a study conducted in Asia, it was found that as school success levels increase and education becomes more difficult, internet addiction increases indirectly. This has been shown to be associated with depressive behavior disorder, introversion, and anxiety. ${ }^{28}$ When studies of addiction in Turkey are examined, it was found that they were generally conducted in a single type of school and they were not categorized based on their education system. According to their education system, schools are in three main categories in Turkey. According to the data of the Ministry of National Education, the science achievement levels are divided into categories as science high schools, which provide science-intensive education, vocational and technical high schools that provide technical education, and Anatolian high schools. In our study, the school group with the highest internet addiction rate was science high schools with high school success level and more difficult education process in accordance with the findings in the literature. We think that this rate in science high schools is due to the difficulty of the education process, the expectation of the end results of education by families, intensive lesson programs and exam stress. While developing programs and projects to reduce addiction seen in high school students, there is a need to organize alternative social programs other than the internet, especially for those students who are under stress.

The most important means of internet addiction have been shown in many studies as smartphones and game consoles. It is stated that smart phones are a means of communication with students and families, and the prevalence of social media usage on these phones has extended the internet usage time in students. With the fact that smartphones are small and portable, it is stated that the long-term habit of using the internet and the unsupervised nature of this period constitute the basis of addiction. ${ }^{29}$ While the rate of having a smartphone in the world continues increasingly every day, it is thought that approximately two out of every three people have a smartphone. ${ }^{30}$ This is more common especially in Turkey; it has been reported in studies on smartphones that about eight in ten young people among adolescents have smartphones. ${ }^{31}$ In our study, it was determined that more than nine of every ten students had smartphones. The proportion of those who have a computer at home was about six out of ten students, while the rate of those who had a game console was three out of ten students. While there was a significant relationship between internet addiction levels and the rate of having smartphones, no significant relationship was found between computers and game consoles. The data shows us that the use of smartphones should be targeted especially when determining addictionfighting strategies. We think that family physicians should question the time spent on their smartphones in this age group, and that families should follow the time spent on smartphones should they have complaints about it and offer solutions specific to their families.

Patients, who go to family physicians, primarily with low back and neck pain are usually firstly arranged for symptomatic treatment and called for check-ups with appropriate exercise recommendations. If there is no improvement in check-ups, it is referred to the relevant departments for the relevant radiological examinations, including direct radiographs. It has been shown in studies that family physicians know their strategies to combat pain and decrease pain in follow-ups, which is an important goal that increases the quality of life in all patients. ${ }^{32}$ In studies with adolescents, it has been shown that musculoskeletal system pain is related to internet addiction, and as the IAT scores increase, musculoskeletal pain increases. $^{33-35}$ It has been shown in studies conducted in Turkey that the amount of time spent on smartphones has a significant positive relationship with lower back and neck pain. ${ }^{36}$ In our study, a significant relationship was found between lower back \& neck pain and IAT scores. Especially in students with high addiction scores, it was determined that lower back and neck pain was higher. A meaningful relationship was found between having a smartphone and neck pain. The data shows that adolescents, who go to family physicians with complaints of back and neck pain, should apply an IAT and should question whether they have a smartphone in the neck pain and how long they should spend time with a smartphone. This important data should be used while preparing the treatment and making recommendations, if necessary, the family should be included in this process and the use of smartphones should be reduced. Thus, the pain process can be managed more effectively.

The most important health complaint seen in those who use monitored instruments for a long time is eye pain and eye symptoms. ${ }^{37}$ In a study conducted by Dong Ju Kim et al. in Korea, it was reported that complaints of dry eye syndrome, tired eyes, pain in the eyes, burning and itching in the eyes increased with the smartphone usage. ${ }^{38}$ In another study conducted for high school students in Europe, it was reported that eye health problems were among the first findings of problematic internet use. ${ }^{39}$ Health problems around the eyes such as burning and pain have been detected in one 
out of every two people according to a study about internet use in Turkey. According to this study, eye-related complaints take the first place in the ranking of symptoms seen on the internet addiction. ${ }^{40}$ In our study, the level of complaints of burning, stinging, and pain in the eyes was about ten times higher in those who were addicted than those who had normal levels of internet usage. There was a significant relationship with both having a smartphone and having a computer and game console at home when it comes to complaints regarding eyes. The data also displays that in adolescents, who go to family physicians with complaints such as burning, itching pain, and stinging in the eyes, family physicians should also question them about their eyes in terms of internet addiction in addition to visual examination.

The strongest part of the study is that it took place in the Çorlu district of Tekirdağ province, which is one of the most common emigration spots in Turkey with it being an industrial zone and having higher job opportunities than other cities. Another important factor that it provides data in proximity of high school students in general Turkey since it attracts immigration from all over the country.

\section{CONCLUSION}

The study shows that internet addiction is an important and common problem in adolescents. Internet addiction increases, as the age of adolescents increases. The risk of internet addiction is equal in both genders, and smartphones, which are very common among adolescents, are the most important risk factor for the spread of internet addiction. The risk of internet addiction is higher among those studying in private schools, children of families with high socioeconomic level, and students with difficult and stressful school groups such as science high school. Since internet addiction can cause muscle-joint pain and eyerelated symptoms, this relation should also be carefully questioned and treated during the adolescent examination. Adolescents and parents should be informed and monitored by the family physician about the subject. Developing social projects for taking protective measures before high school age, raising awareness of the media and families, and putting guidance in school will protect our young people from the musculoskeletal system and eye problems that may occur in the future.

Acknowledgments: Thanks to Çorlu District National Education Directorate. (Due to the permitting and facilitating effects of working in schools on data collection)
Thanks to Şeyma Gülüzar ÖZCEYLAN, Mimar Sinan Anatolian High School-biology teacher, (Because of organizing data collection in high schools and its contribution to the sampling of data)

Thanks to Zehra BARIŞ, Mimar Sinan Anatolian High School-ICT teacher. (Due to contribution to the data collection process in schools)

This manuscript had never presented oral or poster presentations at local, regional, national, or international meetings.

There is no disclosure of any prior publications or submissions with any overlapping information

There is not any potential conflict of interest, real and perceived, for all named authors.

\section{REFERENCES}

1. Güçdemir Y. Computer networks, internet development and information pollution. Istanbul University Journal of Communication Sciences, 2003;17:371-78.

2. Kalaitzaki AE, Birtchnell J. The impact of early parenting bonding on young adults' internet addiction, through the mediation effects of negative relating too thers and sadness. AddictBehav, 2014;39(3):733-36

3. Güneş NA, Akbıyık Dİ, Aypak C, Görpelioğlu S. Social media dependency and sleep quality in high school students. TurkishJournal of FamilyPractice 2018; 22(4):185-192

4. Badenes-Ribera L, Fabris MA, Gastaldi FGM, Prino LE, Longobardi C. Parent and peer attachment as predictors of facebook addiction symptoms in different developmental stages (early adolescents and adolescents). Addict Behav. 2019;95:226-32.

5. Durualp E, Çiçekoğlu P. Investigation of the loneliness levels of the adolescents who are living in an orphanage in term of internet addiction and various variables. The Journal of Graduate School of Social Sciences 2012; 15(1):29-46.

6. Egger, O. \& Rauterberg, G. W. M. Internet behaviour and addiction. Zürich: Swiss Federal Institute of Technology 1996. Accessed from: pure.tue.nl/ws/files/4392817/587150.pdf :13134. Accessed time: 10.10 .2020

7. İskender $\mathrm{M}$, Akin A. Social self-efficacy, academiclocus of control, and internet addiction. Computers\&Education 
8. Kawyannejad, R, Mirzaei, M, Valinejadi A, Hemmatpour B, Karimpour K, AminiSaman $\mathrm{J}$, et al. General health of students of medical sciences and its relation to sleep quality, cell phone overuse, social networks and internet addiction. BioPsychoSocial Med 2019.

Accessed from: https://doi.org/10.1186/s13030-019-0150-7 Accesed time: 10.10 .2020

9. Ayas T, Horzum MB. Internet addiction and internet parental style of primary school students. Turkish psychological counselling and guidance journal 2013; 4(39):46-57

10. Young SK. Internet addiction. Am BehavSci 2004; 48(4):402-15.

11. Kutlu M, Savcı M, Demir Y, Aysan F. Turkish adaptation of Young's Internet Addiction TestShort Form: a reliability and validity study on university students and adolescents. AnatolianJournal of Psychiatry 2016;17(Suppl.1):69-76

12. Zhang MWB, Lim RBC, Lee C, Ho RCM. Prevalence of internet addiction in medical Students: a meta-analysis. Acad Psychiatry. 2018;42(1):88-93. Doi: 10.1007/s40596-0170794-1.

13. Özgen F, Bavlı Ö. Investigation of internet addiction and personality relationship among university students. IJSETS 2017;3(4):129-41.

14. Chung TWH, Sum SMY, Chan MWL. Adolescent internet addiction in Hong Kong: Prevalence, psychosocial correlates, and prevention. J Adolesc Health. 2019; 64(6):3443. Doi: 10.1016/j.jadohealth.2018.12.016.

15. Lau JTF, Gross DL, Wu AMS, Cheng KM, Lau MMC. Incidence and predictive factors of internet addiction among Chinese secondary school students in Hong Kong: a longitudinalstudy.

SocPsychiatryPsychiatrEpidemiol, 2017;52(6):657-67.

16. Bilyk B, Goodman R. Prevalence of child and adolescent psychiatric disorders in Southeast Brazil. Journal of The American Academy of Child and Adolescent Psychiatry 2004;43(6):727- 34.

17. Cash H, Rae CD, Steel AH, Winkler A. Internet addiction: A brief summary of research and practice. Curr Psychiatry Rev. 2012; 8(4):292-98.

Doi:10.2174/157340012803520513
18. Satan A. The factors influencing the internet addiction of secondary education students. Eurasian Journal of Educational Research 2013; 13:131-48.

19. Sayyah M, Khanafereh S. Prevalence of internet addiction among medical students: a study from Southwestern Iran. CentEur J PublicHealth. 2019;27(4):326-29. Doi: 10.21101/cejph.a5171.

20. Mazhari S. The prevalence of problematic internet use and the related factors in medical students, Kerman, Iran. AddictHealth 2012; 4 (3-4):87-94.

21. Cao H, Sun Y, Wan Y, Hao J, Tao F. Problematic internet use in Chinese adolescents and its relation to psychosomatic symptoms and life satisfaction. BMC Public Health. 2011;11:802. Doi:10.1186/14712458-11-802.

22. Dufour M, Brunelle N, Tremblay J, Leclerc D, Cousineau MM, Khazaal Y, et al. Gender difference in internet use and internet problems among Quebec High School students. Can J Psychiatry. 2016; 61(10):663-68. Doi: 10.1177/0706743716640755

23. Qian D. Gender, grade and personality differences in internet addiction and positive psychological health among Chinese college students. Primary Health Care 2016;06. Doi:10.4172/2167-1079.1000248.

24. Öksüz Ö, Karaca F. Internet addiction of gender, with problem internet use, cyber bullying and cyber effects on victimal variables: a meta analysis study, 2019. Accessed from: https://katalog.marmara.edu.tr/veriler/yordamb t/cokluortam/44177FB8-D508-6E46-8FEA5A8DEA97B413/5d836b49e41b3.pdf. Accessed time: 10.10 .2020

25. Lawal AM, Idemudia ES. Gender difference, class level and the role of internet addiction and loneliness on sexual compulsivity among secondary school students. International Journal of Adolescence and Youth 2018;23(4):422-30

Doi:10.1080/02673843.2017.1406380

26. Wu X, Chen X, Han J, Meng H, Luo J, Nyndegger L, et al. Prevalence and factors of addictive Internet use among adolescents in Wuhan, China: interactions of parental relationship with age and hyperactivity- 
impulsivity. PLoSOne. 2013;8(4):e61782. Doi:10.1371/journal.pone.0061782.

27. Moral R, Kumcağı $1 z$. Internet addiction in adolescence: Evaluation from mother, father and peer relationship perspectives. ODU Journal of social sciences research 2019; 9(2):335-46.

28. Li X,Luo X, Zheng R, Jin X, Mei L, Xie X, et al. The role of depressive symptoms, anxiety symptoms, and school functioning in the association between peer victimization and internet addiction: A moderated mediation model. Journal of Affective Disorders 2019; 256(1):125-31.

29. Savcı M, Aysan F. Technological Addictions and Social Connectedness: The Predictor Effect of Internet Addiction, Social Media Addiction, Digital Game Addiction and Smartphone Addiction on Social

Connectedness. TheJournal of
PsychiatryandNeurologicalScience 2017; 30:202-16.

30. Kwon M, Lee JY, Won WY, Park JW, Min J, Hahn C, et al. Development and validation of a smartphone addiction scale (SAS). PLoSOne 2013;8(2):e56936.

Doi: 10.1371/journal.pone.0056936

31. Şar AH. Examination of loneliness and mobil phone addiction problem observed in teenagers from the some variables. The Journal of Academic Social Science Studies International Journal of Social Science 2013; 6(2): 1207-20.

32. Olubusola J, Chidozie M, Oyinade A, Adebimpe O, Taofeek A, Adaobi O. Relationship between physical activity and back extensor muscles' endurance to the risk of low-back pain in school-aged adolescents. TAF
Preventive Medicine Bulletin 2011;10(4):415420.

33. Yang G, Cao J, Li Y, Cheng P, Liu B, Hao Z,et.al. Association between internet addiction and the risk of musculoskeletal pain in Chinese college freshmen - A cross-sectional study. Front. Psychol. 2019;10:1959. Doi: 10.3389/fpsyg.2019.01959

34. Kim HJ, Kim JS. The relationship between smartphone use and subjective musculoskeletal symptoms and university students. $J$ PhysTherSci, 2015;27(3):575-79.

35. Gustafsson E, Thomée S, Grimby-Ekman A, Hagberg M. Texting on mobile phones and musculoskeletal disorders in young adults: A five year cohort study. ApplErgon 2017;58:208-14.

36. Günal A, Pekçetin S. Relationship Between Smartphone Addiction and the Pain in Cervical Region-Upper Extremity among University Students. STED 2019;28(2):114-119.

37. Rocha LE, Debert-Ribeiro M. Working conditions, visual fatigue, and mental health among systems analysts in São Paulo, Brazil. Occup Environ Med. 2004;61(1):24-32.

38. Kim DJ, Lim CY, Gu N, Park CY. Visual fatigue induced by viewing a tablet computer with a high-resolution display. Korean $J$ Ophthalmol. 2017;31(5):388-93. Doi: $10.3341 /$ kjo.2016.0095

39. Černja I, Vejmelka L, Rajter M. Internet addiction test: Croatian preliminary study. BMC Psychiatry. 2019;19:388.

Doi: $10.1186 / \mathrm{s} 12888-019-2366-2$

40. Nazik F, Güneş G. Problematic internet usage and healthy lifestyle behaviors in university students. Cukurova Medical Journal, 2019;44(Suppl 1):41-48. 